\title{
PHILOSOPHY AND METHODOLOGY OF DEFINITIONS OF HISTORY
}

\begin{abstract}
This article suggests a complex unity of definitions of history which should serve for the elucidation of the essence and true adequacy of the science of history to its design. Our conception of history is based on the works of Father of Armenian's History Movses Khorenatsi ( $5^{\text {th }}$ century). The science of history is interpreted following our conception of "hermeneutics of wisdom" developed on the basis of H.-G. Gadamer's "philosophical hermeneutics" which specificity I have already explicated as "hermeneutics of truth" in my monograph "Hans-Georg Gadamer's philosophical hermeneutics". In this article, the conceptual and methodological achievements of both these conceptions: "hermeneutics of truth" and - as its perfected implication - "hermeneutics of wisdom", important for philosophy of history that is understanding of nature of history are used. In formulating definitions of history is used the logical-methodological instrument of the prominent Medieval Armenian philosopher David the Invincible $\left(5^{\text {th }}-6^{\text {th }}\right.$ centuries). The definitions of history are distributed into three main classes: separately by its subject of study, its fulfilment, and jointly - by its subject and fulfilment. The formulated set of definitions of history should serve for a deeper understanding of Movses Khorenatsi's heritage as well as for adequately revealing the truth of "being-of-history as such".
\end{abstract}

Keywords: history, philosophy of history, hermeneutical method, understanding, interpretation, definitions by the subject, definitions by the fulfillment.

\section{Introduction}

The problem of definition has already been considered by the thinkers of ancient Greece, who, in particular, were interested in such a fundamental problem as the elements of the universe, and, accordingly, its definition (see Diels, 1952; Freeman, 1970). The subject of instructive discussions of the famous Socratic conversations were definitions of the concepts under discussion, a detailed account of which in Plato's dialogues served as the basis for extracting from them the Socratic method of cognition of truth - the doctrine of maieutics. One of the vertices of human thought is the Aristotelian theory of definition, which was universally recognized by many generations of philosophers, including the doctrine of the essence and types of definitions developed by the distinguished philosopher of Medieval Armenia David the Invincible (V-VI centuries).

The objective of this article is to review the definitions of history and suggest new definitions which in their unity could elucidate the sense and essential aspects of the science of history. The general guiding line of author's conception is the 
principle that the mode of existence of an object should be its adequacy to its design. Accordingly, the true sense of the history of nations and the mankind, in general, is interpreted as the adequacy of their life, identity, and culture to their design.

The fascinating richness of human history has inspired many historians and writers to formulate a multifaceted set of appealing definitions and characteristics of history. Some of them are brilliant short aphorisms: "The history of the world is the world's court of justice" (Friedrich von Schiller). "The history of the world is but the biography of great men" (Thomas Carlyle). Others bring to readers' attention paradoxical characteristics of history: "Poetry is nearer to vital truth than history" (Plato). "History is the science of what never happens twice" (Paul Valery). There are also authors demonstrating the moral approach to history: "To remain ignorant of things that happened before you were born is to remain a child" (Cicero). "Those who cannot remember the past are condemned to repeat it" (George Santayana). Some writers suggest radically optimistic or radically pessimistic interpretations of history: "What experience and history teach is this - that people and governments never have learned anything from history or acted on the principles deduced from it" (Hegel). "History fades into fable; fact becomes clouded with doubt and controversy; the inscription moulders from the tablet; the statue falls from the pedestal. Columns, arches, pyramids, what are they but heaps of sand; and their epitaphs, but characters are written in the dust?" (Washington Irving). "The value of history, then, is that it teaches us what man has done and thus what man is" (R. G. Collingwood).

There are many approaches concerning the essence of history also among professional historians. One of the most popular traditional forms of history was an epic narrative glorifying the nation's heroes and kings. "History is a narration of the events which have happened among mankind, including an account of the rise and fall of nations, as well as of other great changes which have affected the political and social condition of the human race", wrote John J. Anderson by the end of $19^{\text {th }}$ century (Anderson, 1876).

Some historians like to put emphasis on separate factors of history like time (Braudel, 1982), subjectivity of historical research (Carr, 1961), the role of human consciousness (Febvre, 1922), "disequilibrium" and "dysfunction" in social relations (Stone, 1996), history as a literary art, serving to transport readers back in time (Creighton, 1980), the role of Enlightenment in European history (Himmelfarb, 2005). Many modern researchers of the science of history put emphasis on events having a significant role in social-political developments (for instance, M. Weber, M. Bloch, H. J. Muller). The author of this article in his general approach follows the hermeneutic school of F. Schleiermacher, W. Dilthey, M. Heidegger, H.-G. Gadamer and P. Ricoeur (see Schleiermacher, 1998; Dilthey, 1996; Heidegger, 1962/1927; Gadamer, 2006/ 1975; Ricoeur, 1981).

Why is it necessary and preferable to define history? David the Invincible wrote: “... if a man wishes to conceive and think of something rightly, he must first know the nature of this thing that is, its definition" (David the Invincible, 1983, p. 23). Because the definition is "a short statement which reveals the nature of the thing" (David the Invincible, 1983, p. 27). Thus any thought that sums up the contemplation over the true existence of "history" and discloses by short 
formulation the nature of history is the definition of "history".

So what kind of order of inquiry is possible to disclose the nature of history? David the Invincible regarding all the existing things, including also "philosophy", "history" or any other science suggested the following succession of questions for their study: "Whether it exist?", "What is it?", "What sort of thing is it?", “ What purpose does it exist for?" (David the Invincible, 1983, p. 3).

One more fundamental philosophical question has a principle importance for me - "How is its existence - the potential and the realization?" I mean, how is the mode of existence that is fundamentally inherent to this concrete entity (namely, history) and was the existence of that entity implemented by its calling and the truth of its own existence or, in this case, was the existence of this being implemented untruly?

All these queries we are going to examine keeping in mind the fundamental work "History of Armenians" of Father of Armenian's History Movses Khorenatsi. The conceptual and the methodological basis of the present investigation is the "hermeneutics of truth" and based on it and developed further by an author the conception of "hermeneutics of wisdom". Accordingly, my investigation of the "History of Armenians" of Moses Khorenatsi is carried on in the horizon of the observable field of meanings, opened by the conception of the "hermeneutics of wisdom" and "hermeneutics of truth". In my monograph by critical consideration is understood and interpreted the meaning and counsel of wisdom that reveals the truth of Khorenatsi's historical-scientific conception and according to its implication - the truth of "being-of-history as such" (Khocharyan, 2016).

Dealing with Medieval Christian sources one should take into account the specificity of religious life-mode and Christian scholarship of thinkers in regard to the entire essence of the being - "divine and human realities". The true revelation of the meanings that disclose the truth of the events of life and culture, can be realized by hermeneutical methodology - namely in the meaning-horizon of the conception of "hermeneutics of truth" according to its destiny and the very essence. In this regard it is essential to fix, that for the perpetration of the fullness of the aforesaid intention of the undertaken research it is necessary and preferable by the conception of the true destiny of hermeneutics and all the tradition of its historical being and, in particular, the possibilities of "the art of interpretation of the holy fathers" ("Sacred Hermeneutics") and modern philosophical hermeneutics - to understand and interpretively explicate not only the historical-scientific conception of Movses Khorenatsi, but also the truth and counsel of wisdom of the pure empirical historic content of his scientific conception.

The exegetics of the medieval holy fathers and the modern conceptions of the theoreticians of the "philosophical hermeneutics" created by mutual complementarity of their essential ideas the principle possibility to call for life the conceptions of "hermeneutics of truth" and "hermeneutics of wisdom". These conceptions explicate the truth of understanding and interpretation and by means of them - the very truth of divine and human realities, and also the truth of philosophy, theology, human and social sciences, medieval studies, in particular, and the history itself. In regard to the above mentioned fundamental specificity of the problematic of medieval studies, this conception of hermeneutics presents in itself a necessary and preferable openness, a potency of a developed rational theory of under- 
standing and interpretation. The hermeneutics, in general, and especially the "hermeneutics of truth" or the "hermeneutics of wisdom" have as their destiny, the foreseeing intention and execution (fulfilment) of its idea - to explicate the necessary and preferable mode of understanding and interpretation, and by this - the genuine meaning and counsel of wisdom disclosing the truth-of-being of all entity and just of culture itself. With such self-understanding of his destiny, the hermeneutics and, particularly, "the hermeneutics of truth" (and based on it "the hermeneutics of wisdom") investigates all the phenomena, theories and specifically "history" from the "inside".

The main issue of my aforementioned monograph (Khocharyan, 2016) is just the understanding and interpretation of historical-scientific conception of Movses Khorenatsi and according to this conception and its implications the revelation of "the-being-of-history as such" conducted by hermeneutical methodology. So we would like to point out that Movses Khorenatsi by presenting his historical conception and its necessary components in his fundamental work "History of Armenians" did not suggest them in the form of explicit and concentrated formulations but rather they are spread all over the pages of his historical work. His theory of history and in essence his historical conception, partly explicitly and partly implicitly, are interwoven with the empiric history in his "History of Armenians".

In my opinion, for each historian, philosopher, and wise reader it is essential to understand not only what is said in a given text concretely, but also what horizons of meanings are opened by the said and henceforth what is following from the said in regard of the theory of history and just in regard of the truth of history. The very goal and preferable task of this investigation is to understand in all the works of historians what is concretely said in the texts and/or by the texts and by reconsidering their authors thoughts and bring the movement of thought to its completion - to the true sense of historical events, to the disclosing of their advice of wisdom, to embracing of the discovered wisdom of history.

\section{Classic Definitions of History}

Undertaking the review of definitions of history suggested during the development of historiology it is important to examine some significant examples. Actually, we'll limit us mainly by discussing two of them, the first of them from the Antic Greek historiology, the other from the modern time historians.

What is the subject of history, what is the field of study of historiology? I would like to start the analysis of this question by reiterating Aristotle's idea that historians speaks of things that have happened" (Aristotle, 2006, 145 1b145 12b). Wherein, history predominantly speaks about the things "that are particular", in contrast to poetry, which "speaks more of things that are universal" (Aristotle, 2006, 145 1b-145 12b). And "what is particular is what Alcibiades did or what was done to him (bold by R. K.)" (Aristotle, 2006, 145 1b-145 12b). Thus, according to Aristotle, the subject of history is that what happened or took place in reality, that is events and human actions that nowadays belong to the past.

It should be additionally mentioned that in ancient Greek historiography the subject of history is presented by the events and happenings of life that are subject to fixation and disclosing through investigation. According to this Aristotelian characteristic, the subject of history principally involves in it all the events by the criterion 
that they indeed had taken place and should not be neglected and must be understood and every event should get its truth by historical interpretation. Taking into account the above characteristics, the Aristotelian definition of history could be formulated as follows: history is a science that investigates all the past events of life and their causes.

In regard of Khorenatsi conception of history C. Sargsyan has written the following: "Narrating history he had two basic principle points: the first - the wholeness of the information got from historical sources, the second - historiclogical theoretical view concerning the essence of history... History is a true and reliable reconstruction of the happenings and phenomena of the past" (Sargsyan, 2006, p. 18). As we see, this interpretation of the essence of history is very close to the Aristotelian above discussed position.

Deliberations on the understanding and definition of history as science were accomplished in modern times also. In this regard, special interest deserves the definition of history as a science in historical meditations of the prominent specialist in medieval history and just contemporary historian, supporter of the discussions of theoretical problems of history and innovator Marc Bloch. Endeavouring to formulate his understanding of history, M. Bloch first mentions the meaning of history in ancient Greek as "investigation" and deliberates: "The language preserves the name "history" for all the investigations of changes in the flow of time" (Bloch, 1992/1953, p. 17). In his formulation, a definition of history is already present, according to which history is a science that investigates temporal changes. Understanding history this way and using accordingly the term "history" in practice, the historical studies by different sciences of their subjects principally could not be distinguished from the "histories of historians".

The histories of historians and modern investigations in the case of non-critical approach to the nature of history, in essence, by pure empiric questioning and fulfilment of the field of history, willingly-unwillingly are fulfilled and self-understood only as linear temporal "history of events and actions". As an answer to the principal question "What should be a history?" M. Bloch attempts to re-examine this traditional approach. He finds it necessary to return to the question of "revealing the nature of history" and by critical contemplation and correction attempts to re-understand and re-define the study subject of history and accordingly - the essence and nature of history. By correcting the study subject of history and by the consistent train of thoughts regarding the nature of history and understanding and interpreting its being as such M. Bloch asks: "What happens each time when the interference of history appears necessary and useful?" and answers immediately: "The humanness appears" (Bloch, 1992/1953, p. 17). Completing his conclusion, Bloch recalls the well-known idea that "the study subject of history is the man" and formulates it more correctly - "the study subject of history are men", since "to the science of diversity is more adequate not the singular but rather the plural" (Bloch, 1992/1953, p. 18). Really, history deals with human things, yet it is notable that this idea is not a formula that completely distinguishes history in the set of humanities and social sciences and discloses its nature or its truth as such, but it only points out the genus of the study subject of history. To reach a more definite and grounded disclosure of history, the prominent historian writes: "History wishes to see the people even behind the driest documents completely alienated from their creators" (Bloch, 
1992/1953, p. 18), and, as tells Lucien Febvre, to see "not only one more man and never simply men, but human societies, organized groups" (Bloch, 1992/1953, p. 18). M. Bloch recalls also the idea of Jules Michelet, that history is the study of social man and then recalls also the words of Fustel de Coulanges "history is not a heap of facts of the past, but a science regarding human society" and then adds on the same page that "here the role of the individual in history is rather diminished: "man in society" and "societies" are two not equivalent notions" (Bloch, 1992/1953, p. 18).

\section{The Calling of History}

By this kind of definitions, the being and nature of history is presented to the human spirit and thought by their definite quality, but is this quality of presentation of history the one in which history is presented by its calling and by the most preferable and complete truth of being?

By these definitions, the history or the nature of history and/or the being of history as such allow simply to tell or retell and repeat related to various diverse problems also the untrue understanding and self-understanding of the happenings of life. According to Movses Khorenatsi's conception, the calling of history and the meaning of the truth of its being is not only bringing to narration the happenings of the past and/or the present and thus making history identical or similar to already fulfilled or not yet fulfilled deeds of the untrue being. The sense of the being of history does not suppose simply telling and retelling in different relations the untrue understanding and self-understanding of events and happenings of the human life in the past.

We would like to mention also that Aristotelian definition of history does not take into ac- count the principle moment of human choice. Human cognition and science can't include the entire wholeness of the world and in it - of events of human life. To these contemplations on the subject of history is also related Mark Bloch when he is asking "What is history?" and referring the well-known answer that "History is a science about the past", he writes: "Even the idea that the past could be the object of science is absurd. How it could be possible without preliminary selection to make phenomena a subject matter of cognition - only by a sole common feature that they are not contemporary to us?" (Bloch, $1992 / 1953$, p. 16). Indeed, to become a subject of history it is far from being sufficient to be an event already fulfilled and belonging to the past (Kocharyan, 2016, pp. 527-529).

History is not a "heartless and soulless" mechanism but rather a human science about the realities of human life. In the human thoughts, words, deeds, and entire life, potentially and also in reality, always are present the predisposition, content, and choice - the inborn qualities of the cognitive human identity. And history by principle priority has the fulfilled and chosen vision of its subject. In "what should be said" of history contained in its lines and whole texts the historian puts into it love and vigour, feelings and thoughts, worry and search, examination and contemplation.

History is for man. History discloses the truth of human motifs and actions for the goal of improving mankind's self-identity, life and culture. It is not like an indifferent mechanism without consciousness, created and working on principles indifferent to human needs. The calling of history as a science is not a repetition of pure happenings of life, and the scientific nature of history - the revelation of the truth - does not define it in this way and degree. 
The history has already in itself by a predominance principle a choosing approach to its subject. The historian has put into the all that should be told by the lines of history and the whole text and by that addressed to all studylovers who strive for wisdom, virtue and good order his feelings of love and eager, emotions and thoughts, worry and search, examination and deliberation, in short - heart, soul, goodwill and kindness, and entire human life. Here we can mention the similar position of the prominent historian A. Gurevich who pointed out that history belongs to the file and ranks of moral sciences (Gurevich, 1990, p. 7).

\section{The Definition of History by its}

Subject and Fulfillment

Movses Khorenatsi's conception of history is essentially different from the Aristotelian understanding of the being of history as such and of its study subject. I have mentioned earlier in my monograph that according to Movses Khorenatsi's conception history chooses as necessary and preferable for examination and deliberation and considers deserving inclusion in its subject field not all the happenings and human deeds of the past and the given present, but only the significant ones (Kocharyan, 2016, p. 529). The great Armenian historian argues: "But let this be enough said on this subject. For if we were to try to introduce into our history all events from the building of the tower up to our own time, for your edification, when would we arrive at the narrative of the tales that are your particular desire, especially because the task that lies before us is long, and time for mortals is short and uncertain? But I shall begin to show you our own history - whence and how it developed" (Khorenats'i, 1978, p. 81). And on another page he writes: "After these many things are related in this book. But we shall set out [only] what is necessary to our collection" (Khorenats'i, 1978, p. 88). According to Movses Khorenatsi, the subject of history in general, and of Armenian history, in particular, as it was revealed in my monograph, are the significant events of human and also of Armenian national self-identity, life and culture (Kocharyan, 2016, p. 530).

The historical conception of Movses Khorenatsi, in which the subject is presented as an all-embracing totality of all human realities having important significance in enhancing and supporting human identity, and culture, provides a splendid formulation of the definition of history by its subject: History is science studying significant events of human identity, life, and culture - with their causes. Accordingly, in Movses Khorenatsi historical conception, the definition of history should be as follows: History is science studying significant events of the becoming of human identity, life, and culture in the past and at present - with their causes.

In the presented definitions of history are mentioned those specific features that bring history to existence, make it essential regarding the subject of history, yet not by its fulfilment. It should be pointed out also that definitions of all sciences or arts and, concretely of history, by their study subject are theoretical in principle and are aimed at the theoretical cognition of their subject. And the characteristic "significant" must be elucidated and strictly revealed. When the choice should be made "what" and "which" events should be involved into the study object of history, and in this regard, it is said that it should be only significant events, does not it require to query and to choose "what kind" of significance, it should be? It could be said that human identity, individual and societal life, and style of life, in 
general, by their cultural formation comprise the all-embracing and dynamically extending study subject of history. Human identity and multicontent life could have different forms by their nature and degree, yet, not all events, even having certain cultural forms of expression, are chosen to be involved into the subject of history, but only the significant ones, first of all, presenting spiritual values. Taking into account this aspect of our investigation and including it in the definition of history, we get the following formulation.

According to Movses Khorenatsi, history is science studying spiritually significant events of human identity, life, and formed by culture in the past and at present, including the essence of this spirituality.

Indeed, human happenings could be multisignificant - culturally and educationally, socially and politically, in short, spiritually-culturally. What kind of significance have human realities that are included in Movses Khorenatsi's historical studies? These are all those human realities that provide the possibility to understand the quality of national identity and life in the past and at the present, and not only in regard of their realization but also considering their potential perspectives.

Human identity, individual and social life, in other words, all political, social, economic, military, juridical expressions of life experience, words and thoughts, deeds and structures determining the form of being of human identity and its coexistence with other identities, in essence, are products of human activity creations or works of thought, soul and hands just culture in the widest sense of it.

According to Movses Khorenatsi, Armenian history, and history, in general, is not a mere recreation and repetition of events and happenings in their own space and time. History dis- closes the truth of events of human identity, life and culture that express and fulfil their significance and/or sense and make possible the cognition and identification of their power, causes and orderliness.

So what is the theoretical significance and fulfilment of history? It was said above that the theoretical and scientific aspects of the fulfillment of history are the revelation of truth. But how gets this universal scientific formula its concrete and specific expression just in the case of history? The investigation of history in the frame of Movses Khorenatsi's conception has the intention to understand theoretically and disclose interpretively the truth and good in the happenings of the past and present life.

As we can see, in the above formulations not only the notion of truth appears as theoretical but also the notion of understanding. In general, the notion of truth is considered a theoretical component while as practical components appear the good deeds. But as David the Invincible mentions, practical is present in theoretical and theoretical is present in practical, and the theoretical is of a higher priority in regard of practical: "in the first place theory, as this takes precedence over practice" (David the Invincible, 1983, p. 121). “... For theory comes first, since it is through theory and reason that one comes to practice - so that practice should not be without reason and cause" (David the Invincible, 1983, p. 141).

Indeed, the practical component (the good deeds) should be first theoretically understood and only then - realized in life. In historical science and also in all social sciences as a theoretical fulfilment -as the revelation of truth - is presented as a more extended problematic which also includes practical understanding and interpretative revelation of the good. 
So the definition of history according to the subject and fulfilment is as follows:

The history is a science, which reveals the truth of human identity and significant "events and deeds" of human life - with their causes, and the counsels of wisdom expressing the possibility, necessity and preference for their goodordering.

\section{The Care of History}

In the entire fulfilment of history simultaneously with the general scientific and highpriority theoretical component - the revelation of truth - we would like to point out another practical component, which is also a general scientific component though not for every science. Which is it? It should be said that regarding every science, and especially of human and social sciences, together with the theoretical component there should also be mentioned the practical one - "the care". What does it mean - care? What is it aimed at? By the term "care" should it be understood the care regarding the world of human presence. It is important to mention that "care" is essentially significant not only in regard to humanities and social sciences but also in a degree in regard to natural history. What I'm going to say at first glance could seem strange. It would be right to think that in the boundaries of possibility human immediate theoretical and practical presence and influence all sciences have a horizon of their significance and possibility of application, necessity and even preferability in the problematics of the care concerning "lifeworld of human existence".

The above characteristic of the problem of "care" is not sufficient for its understanding, interpretively disclosing, and "seeing" by thoughts in a definitely expressed form, as inherent to history and belonging to it. Which characteristics are important for the revelation of the essence of "care" in the mentioned frame for each significant science, and especially for humanities and social sciences and also already concerning history? These components of the scientific fulfilment which bring concretely to completion the fulfilment of history is the possibility of good-orderly human coexistence and also the path pointing meanings, including the counsel of wisdom.

The disclosure of these components is the goal of every reader striving for understanding for activities in his present and future life. And what is the practical component and the significance and fulfilment of history compared to this general formula? According to Movses Khorenatsi's conception, history by the unity of theoretical and practical components of its fulfillment is always aimed to "reading-lover" persons. History by its theoretical component is directed to those who strive to read and understand the truth and advice of wisdom, while by its practical component history is for persons who wish to realize the understood truth and good for their identity and life in their present and future. Just this twofold unity intention is called to life by a historian-author. It can also be noted, that history is presented differently to the modes of human cognitive soul and openness of thought directed by the theoretical interest and practical care of human identity.

I would like to mention also the idea of "preferable reader" suggested and explained in my monograph above having the goal to create principally and give the possibility to direct and prepare all reading-lovers and study-lovers to become a preferable reader of the narration. The study-lover to wisdom is intended to conceive the horizon and the observable field of 
meanings, where every essentially significant event and also the destiny, sense and counsel of wisdom has happened (Kocharyan, 2016).

"History" as such must be considered not only in all-embracing or dominating generality of its concrete realizations and, possibly, in its nongenuine (untrue) and therefore in its "inauthentic being", but also in regard to what it should be according to its true calling - as an entity in its own adequate being, and thus in its "genuine (true) being", i.e. an entity having its truth in its own being. In this perspective and just according to M. Heidegger's two-component division, history as such is considered in the conditional twofold unity of its being: "history as an entity" and "the being of history".

\section{History and Storytelling}

According to Movses Khorenatsi, history as such principally exists only in the case when the "story-telling is realized". As it was disclosed in our monograph (Khocharyan, 2016), the preferable form of history in the conception of Father of Armenian's history is the historiological historiography. History in its research phase, yet not in oral or written mode, does not come to completion as such. In the process of examination of historic traces of culture, as of historical source, in its creative and yet psychological and mental phase, when the unknown becomes known, history is not expressed and presented to all mankind in its oral or written modes of existence. It means that the essential feature of the history, which expresses the generic feature of wise speech and text, may be mentioned with the notion of "science" and the notion of "logos" jointly too. So, history is a science - an extended "word" ("discourse" or "script") revealing the truth and the counsel of wisdom of the signi- ficant life's bygone: consistent events, deeds, and life-order as well as its significance along with the cause.

History realizes its story-telling verbatim and also allegorically. And in this sense it should be noted, that not only the content of what is told but also the specificity of the form of telling also participate in the becoming of histories theoretical and practical fulfilment.

Let us note that generally for history the mode of telling historical events could be considered as an accidental feature, an accidentia. Because history can be woven orally or written by different forms of storytelling. Surely, in possibilities of linguistic expression the minimal one - telling by verbatim and direct meaning - is necessary for history but this feature is inherent in every speech and text and does not differentiate history from other texts and thus does not comprise and create history as such. Verbatim mode of telling history presents itself not as the specific feature of history but the general property of text-culture, since it is inherent principally to human mode of thinking, which is just narrative, and by this common base it is also inherent to history as a science. This way of reaching the wholeness by connections of parts is just historical as a kind of human speech, and by this general ground, it is inherent to history as a science.

This way of reaching the wholeness by connections of parts is just historical as a kind of human speech, and by this general ground, it is inherent to history as a science.

But for the history of this kind in which there could be together with verbatim meaning also the allegoric meaning - from the becoming of direct happening to the spiritual, from the invisible to the visible, from the spiritualcorporeal reality to the genuinely spiritual and thus to the deeper truth expressing meaning and 
for the disclosing of the advice of wisdom, certainly, it (allegory) can present itself together with own specificity also as necessary and essential specificity of such history. Consequently, the verbatim and allegoric form of storytelling is the necessary and essential feature of the creation of history as such, while the form of story-telling of various other histories - the ways of telling compared to the fixed in the general definition form, could be qualified as particular forms in the just outlined frame.

In essence, in the doctrine of Movses Khorenatsi history is defined and accordingly investigated as a scholarly mode of narration. It can be fixed, that in his historical-scientific conception history is the interconnection of various meanings and in them - counsels of wisdom, revealing the truth of significant bygones of the whole world and in it - human and also Armenian life, by understanding and interpretative explication in spoken and written modes directed to contemporaries and generations.

\section{The Twofold Unity of the Theoretical} and the Practical

It was fixed above as the special feature of the presence of history as such, and now in regard of the definitions of history it should be recalled and restated that according to Movses Khorenatsi, the being of history as such is the twofold unity of the theoretical and practical components of its fulfilment. History as science strives for the self-reflection of its nature, for understanding its being as the twofold unity of the theoretical and practical. What is the possible and necessary ground of this kind division?

For the adequate understanding of the historical conception of Father of Armenian's History, and in particular, of its theoretical and practical nature (as it was mentioned above) David the Invincible's philosophical system has fundamental and essential importance, which reflects the general content of the medieval Christian philosophy (David the Invincible, 1983). For deeper understanding of Movses Khorenatsi's historical and just of historicalphilosophical conception, in my opinion, it is not only possible, but also necessary and preferable to realize David's philosophical conception and, in particular, the application of his understanding of theoretical and practical fulfilment of philosophy.

As it was mentioned above, in David's conception philosophy is divided into theoretical and practical components since by the theoretical are learned all the beings, and by the practical are directed our good deeds (David the Invincible, 1983, p. 121). And philosophy has been divided into theoretical and practical since "human soul poses two capacities - the theoretical and the animal" (David the Invincible 1983, p. 119). According to him, "the subject of the theoretical is all existence, with a view to knowing [it], while the subject of the practical is confined to human souls" (David the Invincible 1983, p. 119). The narratives of history being told in their connection to wisdom are addressed to humans and just perfect the cognitive and moral capacities of the human spirit and thus creating of the present and future identity and good-order of life of the "reading-lover" contemporaries and coming generations.

In Movses Khorenatsi's conception history according to its calling, in its scientific-theoretical and scientific-practical twofold-unity of being as such is grounded and implemented not only by cognitive and theoretical interest, as each scientific-theoretical history, but also by the practical care of spiritually enhancing and good- 
ordered life-institution of human identity and life.

It is disclosed by our research also that history investigating its subject of study - the significant becoming of human life - understands and interpretively reveals the truth communicating meaning, and in it - the advice of wisdom - and thus creates the theoretical and practical fulfilment of history. History is presented by its connectedness to wisdom as the twofold unity of the theoretical and empirical since just wisdom is both theoretical and empirical. Thus, history by its connectedness to wisdom, with the significance of its intentionfulfilment - addressed to his "reading-loving" contemporaries and also to coming generations - is self-reflecting not only as truth communicating, understanding theoretically and revealing interpretively, but also practically implementing, by human capacity and also by scientifically defined share of participation in life.

Thus, in Movses Khorenatsi's historical conception, the theoretical and practical twofold-unity of the fulfilment of history is that fundamental cause, by which is understood the basic feature of his theory of history - the theoretical and practical of the being of history as such. Keeping in mind this twofold meaning of the being of history, one can mention and fix explicitly the essential feature of the subject of history that defines its "which significance". This is an essential feature since by itself creates, brings into being the history with its whole essence - both with the theoretical and practical capacities and therefore provides the possibility to reveal the nature of history more fully and completely.

Now it is possible to unite the definitions of history by subject and by theoretical and practical fulfilment into one whole definition of the science of history: According to Movses Khorenatsi's historical conception, history generally and Armenian history concretely is a science which communicates the truth of the meaning of the overall events of the genesis and being of nations and concretely of Armenian nation, and therefore of the human and also of Armenian identity and of significant spiritual being, by their causes in the whirlpool of events of this world and this life, including the human and national identity and reviving wisdom, braveness and advice for deeds of all the virtue.

\section{Proximate and Remote Fulfillment}

Father of Armenian's History telling in his work the significant events of Armenian life and therefore of the Armenian Greats - about the identity and deeds of Haik, Aram, Tigran, Vagharshak and others, presents all these as the proximate fulfilment to the aspiration for the understanding of every "reading-lover". He points out as the valuable remote fulfilment of history "eminent in everything that pertains to mankind" (Khorenats'i, 1978, p. 114) - wisdom, braveness, and all the virtues and goodorderliness of life that are perfecting human identity and bring it closer to Godlikeness, within the limits of human abilities. Father of Armenian's History makes the remote fulfilIment of history realizable by the proximate fulfilment of history, i. e. creates in the human identity love for virtues, goodness, homelandbuilding and life-enhancing deeds of Armenian predecessors and, conversely, creates denial and hatred to evil and disastrous deeds. In "Lementations" - the summing up a chapter of his work - he makes the most possible for human innerworld and life-mode to be capable for regret, 
missing for all the goodness, return and aspiration for repentance, opening the way to be self-cleaned in their identity and life-mode from evil and vanity.

Movses Khorenatsi also writes that it is nice and spiritual joy for him - to tell about the virtues and homeland-building good-orderliness of wise and brave men of the Armenian Greats. And "how dear it would have been for me if the Savior had come at that time and redeemed me and if my entrance into the world had occurred in that time if I could delight in their rule and escape from the dangers of the present!" (Khorenats'i, 1978, p. 110).

\section{Conclusion}

According to the viewpoint established in scholarly publications, the being of history in the treatise of Movses Khorenatsi appears as "the science of history". Grounded upon the results of the implemented hermeneutical study of the historical conception of Movses Khorenatsi, as a preliminary conclusion of the investigation, the truth-of-being of history according to his conception and its implications are explicated as an entity, just its nature in its adequate presence. According to H.-G. Gadamer's conception of philosophical hermeneutics, the truth-of-being of an entity, principally intelligible to human understanding, is the uncovered or revealed being of entity, just its presence in human understanding. The truth and the expressing it meaning and wisdom, available for human cognition, are present in understanding, and by understanding, they exist and are affirmed in their presence. According to Movses Khorenatsi, the presence of history is the presence of sense (meaning) and wisdom. The presence of history and of the historical-scientific conception, shaped and contained in it, is the sense (meaning) and wisdom, which create the human selfidentity, life, and culture.

The presence of his history and of interpreted in it "science of history" is disclosed just as the presence of wisdom, contained in "what should be narrated" and in "theory of history", and, as such, is disclosed as a principally preferable possibility of the being-ofhistory. In the treatise of Movses Khorenatsi history is not only something, which "has been" in the past, but also - in virtue of its power to make wise and its spiritualizing significance - is "in its continuing being" for present and future. The presence of history is "the bygone occurring in its continuing being".

In scientific knowledge and, namely, in the "science of history" there is a possibility to present explicitly the counsel of wisdom. In the ancient and especially in medieval historical science the fundamental and at the same time target-problem of the inner connection of "wisdom" and "science" was present in its peculiar understanding; subsequently, as a result of its more essential transformation, this problem has been completely forgotten and not considered and not formulated in the integral problematic of history as a problem of scientific investigation.

To narrate the wisdom, contained in bygones (or yores) of life, is the true calling of history that was originally inherent to it. The calling of history addressed to contemporaries and descendants is identical to the calling of reading history - to reach and comprehend the wisdom itself.

In the treatise "History of the Armenians" of Movses Khorenatsi the being of history is revealed not as a mere empiric history, but - in virtue of its self-understanding - as historiosophy, thus being accepted in scholarly literature 
predominantly in this surprisingly perfect quality of historical-scientific conception. According to his historical-scientific conception, the genuine presence of history is just the symbolic presence of wisdom contained in essential bygones of human identity, life, and culture, presented to the self-identity and life of every "reading-lover". The genuine calling of the being of history and its participation in human life and by it - the truth and the very presence of the idea of history and its fulfillment should be understood and interpreted as the "presence of wisdom" embodied and contained in history, which is dedicated to the perfection of human self-identity, life-mode and culture of contemporaries and generations.

According to Movses Khorenatsi, Armenian history is spiritual science of the entire happenings of the significant becoming of life and of the revealing the truth of the advice of human deeds and just of the advice of wisdom, and in them or just by them the presence of the tender and caring control of the God, making it cognizable through critical understanding and interpretive disclosing, within the limits of human abilities.

Thus Movses Khorenatsi's theory of history and historical-scientific conceptions are revealed as a philosophizing "science of history".

\section{REFERENCES}

Anderson, J. J. (1876). A Manual of General History. New York: Clark \& Maynard.

Aristotle. (2006). Poetics. Newburyport: Focus Publishing/R. Pullins Company.

Bloch, M. (1992/1953). The Historian's Craft. Manchester: University Press.

Braudel, F. (1982). On history. Chicago: Uni- versity of Chicago Press.

Carr, E. H. (1961). What Is History? New York: Vintage Books.

Creighton, D. (1980). The Passionate Observer: Selected Writings. Toronto: McClelland and Stewart.

David the Invincible (1983). Definitions and Divisions of Philosophy. University of Pennsylvania, Armenian Texts and Studies number 5. Chico, California: Scholars Press.

Diels, H. (1952/1906). Die Fragmente der Vorsokratiker. Berlin: Weidmann,

Dilthey, W. (1996). Selected Works, Volume $I V$ : Hermeneutics and the Study of History. Princeton: Princeton University Press.

Febvre, L. (1922). La Terre et l'évolution humaine: introduction géographique à l'histoire. Paris: Renassance du Livre.

Freeman, K. (1970/1948). Ancilla to the PreSocratic Philosophers: A Complete Translation of the Fragments in Diels. Cambridge: CUP.

Gadamer, H.-G. (2006/1975). Truth and Method. New York: Continuum.

Gurevich, A. J. (1990). Srednevekovyi mir: kul'tura bezmolvstvuyushchego bol'shinstva (The Medieval World: the Culture of the Silent Majority, in Russian). Moscow: Iskusstvo.

Heidegger, M. (1962/1927). Being and Time. New York: Harper\&Row.

Himmelfarb, G. (2005). The Roads to Modernity: The British, French, and American Enlightenments. New York: Vintage Books.

Khorenats'i, M. (1978). History of the Armenians. London: Harvard University Press.

Kocharyan, R. (2016). Patmut'yuny' \& hermen- 
\&tikan. Girq 1. Movses Xorenacu patmagitakan hayecakargy'. (History and Hermeneutics. Book 1: Historical-Scientific Conception of Movses Khorenatsi, in Armenian). Yerevan: Matenadaran, Printinfo.

Muller, H. J. (2003/1952). The Uses of the Past: Profiles of Former Societies. Oxford University Press/ Textbook Publishers.

Ricoeur, P. (1981). Hermeneutics and the Human Sciences: Essays on Language, Action, and Interpretation. (J. B. Thompson, Ed. \& Trans.) Cambridge: Cambridge University Press.

Sargsyan, G. Kh. (2006). Patmagitakan hetazo- tut'yunner (Historiography Studies, in Armenian). Yerevan: NAS RA Publication.

Schleiermacher, F. (1998). Hermeneutics and Criticism: and Other Writings. Cambridge: Cambridge University Press.

Stepanyan, A. (2009). On the Basic Ideas of the History of the Armenians by Moses Khorenatsi. Philosophia Antiqua. A series of studies on Ancient Philosophy, (Vol. 116), 183-196.

Stone, L. (1996). The Causes of the English Revolution 1529-1642. London: Routledge.

Weber, M. (1994). Sociological Writings. New York: Continuum. 